\title{
The Effectiveness of Teaching Personal and Social Responsibility Teaching Model in Improving Responsibilities
}

\author{
Ihsan Abdul Patah*, Juntika Nur Ihsan, Amung Ma'mun, Mulyana \\ Suryakancana University \\ Cianjur, Indonesia \\ *Ihsanabdulpatah@unsur.ac.id
}

\begin{abstract}
Responsibility is needed in life. On the other hand, entering the era of globalization, there is a phenomenon of the decline of the student's character. The aim of the study was to determine the effectiveness of the TPSR model in increasing the student's responsibility. The study was a quasi-experimental research with Control Group Pre-test-Post-test design. The research population were the eighth grade students of SMP Negeri 1 Lembang chosen through a purposive sampling technique. The study involved 76 students from two classes who were divided into experimental group and control group. Data collection techniques included observation by using TARE (Tools of Assessing Responsibility-based Education) Wright (2008) and documentation. The data were analysed through independent sample t-test and mann-whitney u-test. The results showed that there was a difference in the effectiveness of the TPSR model compared to conventional model in increasing the student's responsibility in pencak silat learning with t-count $\mathbf{- 6 . 7 3 2}$, significance of 0.000 . The average post-test score of the experimental group was $\mathbf{7 7 . 5 0 0 ,}$, while the average of the control group score was 59.843. The experimental group gain was 0.6247 , while the control group gain was 0.2803 . Thus, the TPSR model is needed in increasing the student's responsibility.
\end{abstract}

\section{Keywords: responsibility, TPSR model}

\section{INTRODUCTION}

Physical education has now become a tool to increase all potentials in students, one of which is an effort to increase the attitude of responsibility. Responsibility has a definition as a person's behaviour to comply with all the rules that exist in the community and in the school environment. Responsibility literally means the ability to respond or answer. That means, responsibility is oriented towards others, provides a form of attention and actively responds to what they want. Responsibility emphasizes the obligation to protect one another [1]. Responsibility means taking care of others, our surroundings and ourselves. Responsibility is often seen by teachers as adherence to rules and role expectations in schooling. Teaching and learning responsibility is an essential part of preparing students for their role in society as responsible citizens [2]. Responsibility is view both as personal characteristic necessary for success in school and as quality to be achieve through schooling [3].
The current phenomenon, a lot of impact caused by a student does not have a responsible attitude (see Table I).

TABLE I. DEVIANT BEHAVIOR OF STUDENTS IN 2017-2018 IN INDONESIA

\begin{tabular}{|c|c|c|c|c|}
\hline No. & Time & $\begin{array}{c}\text { Deviant } \\
\text { Behaviour }\end{array}$ & Location & Source \\
\hline 1. & $\begin{array}{l}\text { Friday, } \\
24 \\
\text { November } \\
2017\end{array}$ & $\begin{array}{l}\text { A junior high } \\
\text { school student was } \\
\text { reported killed } \\
\text { after being } \\
\text { involved in an } \\
\text { inter-student duel }\end{array}$ & $\begin{array}{l}\text { Kampung } \\
\text { Sawah Village, } \\
\text { Rumpin } \\
\text { District, Bogor } \\
\text { Regency }\end{array}$ & $\begin{array}{l}\text { ayobog } \\
\text { or.com }\end{array}$ \\
\hline 2. & $\begin{array}{l}\text { Saturday, } \\
30 \\
\text { Desember } \\
2017\end{array}$ & $\begin{array}{l}\text { Because of the } \\
\text { powder, ABG girls } \\
\text { kill high school } \\
\text { students }\end{array}$ & $\begin{array}{l}\text { Ngliyep Beach, } \\
\text { South Malang }\end{array}$ & $\begin{array}{l}\text { http://w } \\
\text { ww.trib } \\
\text { unnews } \\
\text {.com }\end{array}$ \\
\hline 3. & $\begin{array}{l}\text { Thursday, } \\
1 \text { Februari } \\
2018\end{array}$ & $\begin{array}{l}\text { Heartache } \\
\text { Reprimanded, } \\
\text { Students Hit the } \\
\text { Fine Arts Teacher } \\
\text { to Death }\end{array}$ & $\begin{array}{lr}\text { SMAN } & 1 \\
\text { Torjun, } & \\
\text { Sampang } & \\
\text { Regency, } & \text { East } \\
\text { Java } & \\
\end{array}$ & $\begin{array}{l}\text { jawapo } \\
\text { s.com }\end{array}$ \\
\hline
\end{tabular}

To be able to overcome the low attitude of student responsibility, therefore an effort is needed by implementing an appropriate learning model integrated into pencak silat learning material. When looking at the learning process of pencak silat at this time, teachers still prioritize traditional-based learning, so that the attitude of responsibility of students is less developed and well developed, even though if observed there are eight learning models, such as PSI, DI, Peer Teaching, Inquiry, Cooperative, TGM, SEM [4] and TPSR which can be an alternative to replace traditional learning processes that are no longer effective. TPSR is an appropriate learning model to improve aspects of the attitude of responsibility. This model explicitly teaches children to develop personal and social responsibility through physical activity, which implies a value orientation [4]. The model of personal responsibility and social responsibility (TPSR) is an example of a positive development model. Proposed by Don Hellison to offer children and adolescents who are at risk of lacking social sense, have the opportunity to develop their personal and social skills and responsibilities [5].

The TPSR learning model has four main objectives to be achieved in the context of physical education learning namely 
conclude the results of his research. Experiment is a way to find a causal relationship (causal relationship) between two factors that are intentionally generated by the researcher by eliminating or reducing or eliminating other factors that interfere [16].

Sudjana argues that research design is an experimental design (with each step that is truly identified) in such a way that the information related or needed for the problem being investigated can be collected [17]. In this study, the researcher gave treatment (treatment) by applying the TPSR and conventional pencak silat learning models to the eighth grade students of SMP to see their responsibilities.

Participants in this study were seventh grade students of SMP Negeri 1 Lembang male and female as many as 76 students from two classes as samples, divided into two groups, namely the experimental group and the control group. Sugiyono explains that the population is an area of generalization consisting of: objects / subjects that have certain qualities and characteristics set by researchers to be studied and then drawn conclusions [15]. Based on these explanations, the population in this study was all eighth grade students of SMP Negeri 1 Lembang, totalling eleven classes (grades A to K), with a total of 416 students, consisting of 191 male students and 225 female students. Through the application of the TPSR learning model, it is expected to increase responsibility.

Sugiyono that the sample is part of the number and characteristics possessed by the population [15]. Sampling was carried out through purposive sampling technique. Based on the results of the sampling, the study sample was 17 male students and 17 female students of class $A$ as the experimental group, and 17 male students and 17 female class B students as the control group.

For the purposes of this study, the instrument used is based on TARE (Tools of Assessing Responsibility-based Education) made by [18], which the researcher later adapted to the needs of this study. In this study, the attitude of responsibility adapts from four levels of responsibility based on the Responsibility Level component according to [19], namely: 1). Respect (Respect), 2). Participation, 3). Independence (Self-Direction), and 4). Caring.

Furthermore, to measure the instrument used is the Student Responsibility Self Check [20], is an instrument to evaluate the responsibility of students consisting of five levels of responsibility using a Likert Scale. Likert scale is used to measure attitudes, opinions, and perceptions of a person or group of people about social events or symptoms [15].

Descriptive analysis is carried out to see the tendency of variable frequency distribution and determine respondents' responses to each variable under study. Student answers according to the Likert Scale are scored. Then descriptive analysis of pre-test scores, post-test scores and N-Gain scores included average scores $(\mathrm{x})$ and standard deviation (S). Furthermore, this study uses analysis techniques of independent sample t-test and mann-whitney u-test.
Sugiyono states that the research method is defined as a scientific way to obtain data with specific purposes and uses [15]. The research method used in this study is quasiexperimental research design pre-test - post-test control group design, with a quantitative approach that uses numbers to 


\section{RESULTS AND DISCUSSION}

In this section, the results of the t-test analysis will be described to test the truth that increasing the responsibility of students who use the TPSR model is higher than those using conventional learning. This test can be seen from the results of the pre-test and post-test. This research hypothesis uses the following statistical formula:

Ho: The average responsibility of students who use the TPSR model is lower or the same as those who use conventional learning.

Ha: The average responsibility of students who use the TPSR model is higher than those using conventional learning.

By determining conclusions based on probability:

- If $\mathrm{P}>0.05$, Ho is accepted and Ha is rejected

- If $\mathrm{P}<0.05, \mathrm{Ho}$ is rejected and $\mathrm{Ha}$ is accepted

TABLE II. SUMMARY OF INDEPENDENT TEST OF STUDENT RESPONSIBILITY T-TEST

\begin{tabular}{|l|l|l|l|}
\hline \multicolumn{1}{|c|}{ Variabel } & Mean & \multicolumn{1}{c|}{ tcount } & $\begin{array}{c}\text { Sig. } \\
\text { (2-tailed) }\end{array}$ \\
\hline Pre-test & 39,375 & 1,182 & 0,242 \\
$\begin{array}{l}\text { a. Eksperiment } \\
\text { b. Control }\end{array}$ & 42,500 & & \\
\hline Post-test & & & \\
a. Eksperiment & 77,500 & $-6,732$ & 0,000 \\
b. Control & 59,843 & & \\
\hline
\end{tabular}

Based on table 2 above can be seen the price of $t$ count pretest at equal variances assumed is 1,182 with the value of Sig. (2-tailed) of 0.242. Thus P 50.05 , Ho is accepted and $\mathrm{Ha}$ is rejected. This fact shows that the average pre-test in the experimental group and the control group is no difference, because the average pre-test in the experimental group is 39.375 while in the control group is 42.500 . The price of $t$ count post-test at equal variances assumed is $-6,732$ with the value of Sig. (2-tailed) of 0,000 . Thus $\mathrm{P}<0.05$, Ho is rejected and $\mathrm{Ha}$ is accepted. This fact shows that the average post-test in the experimental group and the control group there are differences, because the average post-test in the experimental group is 77,500 while in the control group is 59,843. Based on the explanation above, it can be concluded that the hypothesis is proven to be true that the responsibility of students who use the TPSR model is higher than the responsibility of students who use conventional learning. Increased student responsibility based on student pre-test and post-test data with calculation of gain index with Ms. program. Excel and the results can be seen in table 3. below.

TABLE III. GAIN CALCULATION RESUlts

\begin{tabular}{|l|c|l|}
\hline & \multicolumn{1}{|c|}{ Gain } & \multicolumn{1}{c|}{ Category } \\
\hline Eksperiment Group & 0,6247 & Average \\
\hline Control Group & 0,2803 & Low \\
\hline
\end{tabular}

The purpose of this study is to improve the attitude of responsibility of students through the physical education learning process of pencak silat material. The increase that occurred in the attitude of responsibility of students who learn with TPSR, includes: respect, shown by the attitude of students who want to listen to others, can solve a conflict peacefully, do not make a fuss and want to pay attention to the teacher or other students are talking [21], participation and hard work, shown by the attitude of students who want to follow the assignment given by the teacher and want to complete the assignment of the movement. Furthermore independence, shown by the attitude of students who want to do the task independently without the help of a teacher or ask for help from other friends and the last is caring, shown by the attitude of students who want to teach other students who have not mastered the Silat movement.

\section{CONCLUSIONS}

Based on the results of processing and data analysis that the author did, it can be concluded from this research based on the facts and data that the author obtained. The conclusion is the responsibility of students who use the TPSR model is higher than the responsibility of students who use conventional models in learning pencak silat. For students, the TPSR model is a model to change the lifestyle that is less responsible to become a more responsible lifestyle, for example by doing the TPSR model students are more responsible in carrying out the tasks given by the teacher. In addition, it should not make the TPSR model only as a learning model that is applied in schools, but with the awareness that the TPSR model is needed by students to become responsible individuals in the surrounding environment.

\section{REFERENCES}

[1] T. Lickona, "Character matters persoalan karakter bagaimana membantu anak mengembangkan penilaian yang baik, integritas, dan kebajikan penting lainnya lebih dari 100 strategi jitu," Jakarta: Bumi Aksara, 2012.

[2] G. Severinsen, "Asia-pacific journal of health , sport teaching personal and social responsibility to juniors through physical education," pp. 3741, October 2014.

[3] M. Hassandra, M. Goudas, "An evaluation of a physical education program for the development of students' responsibility," Hellenic Journal of Psychology, vol. 7, pp. 275-297, 2010.

[4] J. Fernandez-rio, "Another step in models-based practice : hybridizing cooperative learning and teaching for personal and social responsibility," August 2014.

[5] A.E. Carbonell, "Applying the teaching personal and social responsibility model (tpsr) in spanish schools context: lesson learned" ÁGORA para la Educación Física y el Deporte, vol. 14(2), pp. 178-196, 2012.

[6] K.A.R. Richards and B. Gordon, "Socialisation and learning to teach using the teaching personal and social responsibility approach," AsiaPacific Journal of Health, Sport and Physical Education, vol. 8(1), pp. 19-38, 2017.

[7] D. Hellison, "Teaching responsibility through physical education foreword by daryl siedentop," Champaign: Human Kinetics, 2011.

[8] C. Baptista, T. Dias, N. Corte-real and C. Dias, "Constructing agents of change through the model of personal and social responsibility ( TPSR ): a study of physical education in east timor," March 2019.

[9] D.E.L.A. Cruz, "Original article teachers' perceptions of personal and social responsibility improvement through a physical education based intervention,” JPES®, vol. 19(1), pp. 156-161, 2019.

[10] B.J.S.A. Martínez, A.G. Mármol, A.V. Valenzuela and E. De la Cruz Sánchez, "Aplicación de un programa para la mejora de la 
[15] Sugiyono, "Metode penelitian pendidikan pendekatan kuantitatif, kualitatif, dan R\&D," Bandung: Alfabeta, 2015.

responsabilidad personal y social en las clases de Educación Física. Motricidad," European Journal of Human Movement, vol. 30, pp. 121-129, 2013

[11] I. Pavão, F. Santos, P.M. Wright, F. Gonçalves, "Implementing the teaching personal and social responsibility model within preschool education: strengths, challenges and strategies," Curriculum Studies in Health and Physical Education, vol. 0(0), pp. 1-20, 2018.

[12] P. Martins, A. Rosado, V. Ferreira and R. Biscaia, "Examining the validity of the personal-social responsibility questionnaire among athletes," Motriz: Revista de Educação Física, vol. 21(3), pp. 321-328, 2015 .

[13] P. Wright, "Implementation and outcomes of a responsibility-based physical activity program integrated into an intact," January 2016.

[14] J.E. Romar, E. Haag and B. Dyson, "Teachers' experiences of the TPSR (teaching personal and social responsibility) model in physical education,” Ágora para la educación física y el deporte, vol. 17(3), pp. 202-219, 2015
[16] S. Arikunto, "Prosedur penelitian suatu pendekatan praktik," (edisi revisi vi), Jakarta: Rineka Cipta, 2006.

[17] N. Sudjana, "Metode statistika," Bandung: Tarsito, p. 7, 2005.

[18] P.M. Wright and M.W. Craig, "Tool for assessing responsibility-based education (TARE): a reliability Study," In AAHPERD National Convention \& Exposition, Tampa, FL, April 2009.

[19] D.R. Hellison, "Teaching responsibility through physical activity," Teaching responsibility through physical activity, p. 13, 1995.

[20] A. Suherman, "Implementasi kurikulum baru tahun 2013 mata pelajaran pendidikan jasmani (studi deskriptif kualitatif pada sdn cilengkrang),' Mimbar Sekolah Dasar, vol. 1(1), pp. 71-76, 2014.

[21] N.I. Rahayu, A. Suherman and B.A Jabar, "Jurnal pendidikan jasmani dan olahraga hybridizing teaching personal social responsibility (TPSR) and problem based learning (PBL) in physical education," vol. 3(229), pp. 101-111, 2018 